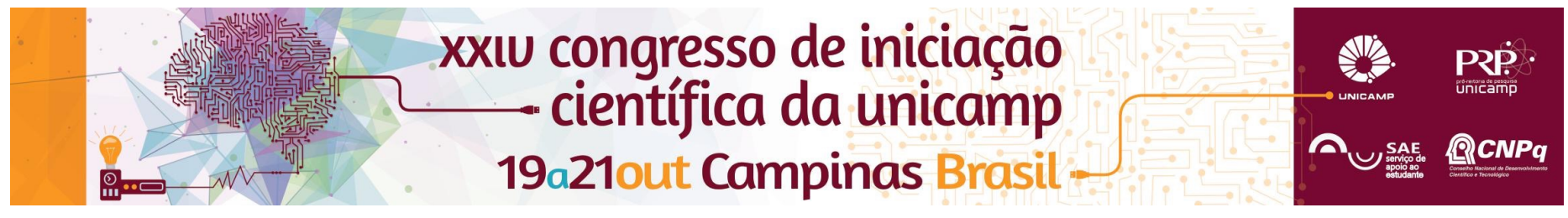

\title{
Tensões entre Educação e Entretenimento na produção televisiva infantil
}

\section{Tobias R. S. de Matos*}

\section{Resumo}

A pesquisa busca analisar e comparar a produção de dois programas infantis educativos: o Rá-Tim-Bum (1990) e o Castelo Rá-Tim-Bum (1994). Para tanto, foi conduzida uma pesquisa documental no Centro de Memória Audiovisual da Fundação Padre Anchieta e realizadas entrevistas com membros das equipes. Como resultado, foi possível explicitar tensões e colaborações entre pedagogos e produtores nos bastidores, bem como comparar a influência que a pedagogia exerceu no desenvolvimento de cada programa.

\section{Palavras-chave}

Televisão Infantil, Educação, Rá-Tim-Bum

\section{Introdução}

Assistir à televisão é uma atividade que está no cotidiano de muitas crianças. Por isso, a programação televisiva participa ativamente na educação do telespectador infantil e na construção de seu imaginário.

No Brasil, é possível destacar a TV Cultura pelo seu largo histórico de produções infantis educativas. $\mathrm{Na}$ presente pesquisa, foram investigados dois programas da emissora proeminentes pela articulação entre educação e entretenimento, sucesso entre crianças e críticos: o Rá-Tim-Bum e o Castelo Rá-Tim-Bum.

Através da análise e comparação do processo de criação de ambos os programas, buscou-se revelar as interações entre produtores e assessores pedagógicos nos bastidores dos programas, explicitando a influência que a pedagogia exerceu na elaboração de cada um deles.

\section{Resultados e Discussão}

O Rá-Tim-Bum (figura 1) surge com o objetivo de suplementar a educação de crianças entre 4 e 6 anos de idade que não frequentavam a pré-escola, através de um programa atraente para o publico infantil. Pelo projeto pedagógico do programa ${ }^{1}$, observa-se a intenção de contribuir para uma certa homogeneidade na formação dos telespectadores. No documento, há uma lista de conteúdos enfatizando habilidades psico-motores e cognitivas que deveriam ser assimiladas pelo público. "Identificar a cor vermelha" e "Segurar corretamente o lápis" são exemplos extraídos do projeto redigido pela assessoria pedagógica, em que foram detalhados conteúdos obrigatórios para os roteiros do programa. Para cada tópico pedagógico, foram criados diferentes personagens e situações que ensinassem de forma divertida. Contudo, os roteiristas do programa revelam que sentiram sua criatividade cerceada pela assessoria. A equipe pedagógica era hierarquicamente superior à equipe de roteirista e por vezes vetava aspectos puramente dramatúrgicos do roteiro. O resultado disso foi uma relação com notórios conflitos entre essas equipes.

O Castelo Rá-Tim-Bum (figura 2) sucede o Rá-Tim-Bum, seguindo o intuito de educar crianças divertindo. Contudo, uma assessoria pedagógica externa foi convidada para auxiliar na criação do novo programa. O projeto pedagógico ${ }^{2}$ redigido pela nova assessoria aponta para a compreensão da televisão como um espaço de educação complementar à escola. Sugere tratar de conteúdos universais do conhecimento dentro do programa, desde que inseridos em contextos significativos para as crianças. Nota-se que foi concedida maior importância para a mediação histórico-sócio-cultural na formação da criança e de suas subjetividades. Assim, foi compreendido que uma dramaturgia bem desenvolvida também educava, dando maior liberdade para os roteiristas do programa. Por isso, ao mesmo tempo que existem personagens para abordar conteúdos pedagógicos, há também um núcleo de personagens centrais que vivem histórias e conflitos diversos. Além disso, os assuntos abordados em cada programa foram levantados a partir de reuniões entre os criadores e a pedagoga, sem existir uma lista de conteúdos obrigatórios a cumprir. Assim, a criação do Castelo Rá-Tim-Bum foi fruto do diálogo entre assessoria e roteiristas, em relação de colaboração e respeito mútuo.

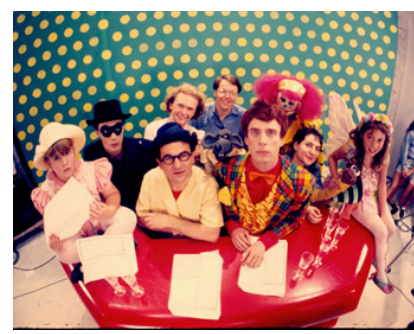

Figura 1. Elenco Rá-Tim-Bum

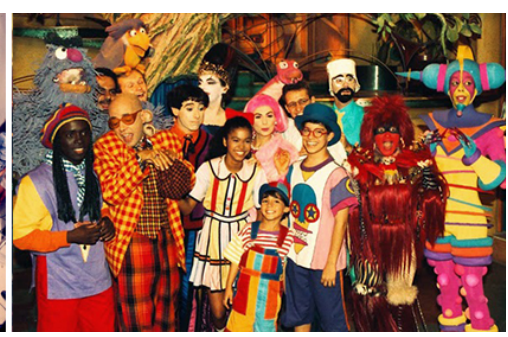

Figura 2. Elenco Castelo Rá-Tim-Bum

\section{Conclusões}

Ambas produções demonstram que é possível criar programas educativos e, ao mesmo tempo, interessantes ao público. Esteticamente criativos, a principal diferença entre eles está na assessoria pedagógica que os embasou. No Rá-Tim-Bum, há uma perspectiva conteudista, pouco aberta para a sugestão dos artistas envolvidos. Já no Castelo Rá-Tim-Bum, houve uma concepção libertária da educação, que entendia a importância dos roteiristas e de suas sugestões criativas.

\section{Agradecimentos}

Entrevistados: Beatriz Rosenberg, Beth Carmona, Cao Hamburger e Zélia Cavalcanti. Centro de Memória Audiovisual FPA: Demócrito Nitão e José Maria Pereira Lopes. Entrevistas compartilhadas: Adriana Maricato de Souza. Orientação: José Armando Valente. Instituição de Fomento: FAPESP.

\footnotetext{
MARQUES, Célia. Rá-Tim-Bum Projeto de Educação Pré Escolar por Televisão. São Paulo:TV Cultura, 1989.

CAVALCANTI, Zélia. Projeto pedagógico para Rá-Tim-Bum II. São Paulo: TV Cultura 1992.
} 